\title{
$700{ }^{\circ} \mathrm{C}$ 級 A-USC 蒸気タービン用低熱膨張 Ni 基超合金 LTES700R
}

倉田征児*1，植田茂紀*1，野田俊治*1，山本隆一*2，角屋好邦*2，中野 隆*3， 田中良典*3，馬越龍太郎*3

\section{Ni-Based Superalloy "LTES700R" with Low Thermal Expansion for Advanced $700{ }^{\circ} \mathrm{C}$-Class Steam Turbines}

Seiji Kurata, Shigeki Ueta, Toshiharu Noda, Ryuichi Yamamoto, Yoshikuni Kadoya, Takashi Nakano, Yoshinori Tanaka, and Ryotaro Magoshi

\section{Synopsis}

Advanced $700{ }^{\circ} \mathrm{C}$ class steam turbines require using Ni-based superalloys instead of conventional ferritic $12 \mathrm{Cr}$ steel which is insufficient in creep strength and oxidation resistance above $650{ }^{\circ} \mathrm{C}$. The superalloys, however, possess quite higher coefficient of thermal expansion (CTE) than the $12 \mathrm{Cr}$ steel. So far authors examined the influence of alloying elements on CTE and the high temperature strength of the Ni-based superalloys. Consequently "LTES700R" was developed for steam turbine, which has low CTE and sufficient creep strength. LTES700R is corrected Mo amount to inhibit the Laves phase and added $W$ to reduce CTE instead of Mo within the range that alfa-tungsten does not precipitate. In addition, Al and Ti, which form gamma-prime, were increased to make up for deteriorating of the strength by Laves phase free. The creep rapture strength of LTES700R manufactured by laboratory forging is higher than that of advanced $12 \mathrm{Cr}$ steel owing to be strengthened by gamma-prime [Ni3(Al, Ti)] phase precipitates. The CTE of LTES70OR is lower than that of Refractaloy $26^{\circledR}$, and slightly higher than that of $12 \mathrm{Cr}$ steel. The phase of LTES700R is stable until $5000 \mathrm{hr}$ heating from $550{ }^{\circ} \mathrm{C}$ to $750{ }^{\circ} \mathrm{C}$.

\section{1. 緒 言}

環境問題への関心が高まるにつれ，温室効果をもたら す $\mathrm{CO}_{2}$ 削減の要求が強くなっている。 このニーズに対応 するため, 発電プラントに扔いては発電効率を高めるた めに高温, 高圧化し, 燃料の使用量を抑えることが必要 である。 日本では現在㧍よそ 20 基の $600{ }^{\circ} \mathrm{C}$ 級超々臨界 圧発電（USC, Ultra Super Critical）プラントが稼動して いるが, 将来的な世界の燃料消費量増加に備え, 蒸気温 度が $700{ }^{\circ} \mathrm{C}$ から $800{ }^{\circ} \mathrm{C}$ に達する A-USC (Advanced Ultra Super Critical）と呼ばれる先進超々臨界圧プラントの開発 が進められている1) 3).
$600{ }^{\circ} \mathrm{C}$ 級蒸気タービンには通常, $12 \mathrm{Cr}$ フェライト系耐 熱鋼が使われているが，A-USC 蒸気タービンでは高温強 度が不足するため $\mathrm{Ni}$ 基超合金の適用が必要となる。 $\mathrm{Ni}$ 基超合金はコスト面や大型品の溶解，鍛造に必要な製造 能力の制約から， ローターなどの高温部の使用に限定さ れ，低温部にはフェライト系耐熱鋼を使用した溶接構造 が必須となる ${ }^{4)}$. ᄂかしながら，一般的に $\mathrm{Ni}$ 基超合金は フェライト系耐熱鋼に比べて熱膨張係数が大きいため, 溶接構造ではローター軸方向や $\mathrm{Ni}$ 基超合金とフェライト 系耐熱鋼との接合部での熱膨張の違いから, 構造が複雑 となる，そのため，溶接構造のローターを作製する場合 には設計時の制約を減らすため, フェライト系耐熱鋼に 
近い熱膨張係数を有する $\mathrm{Ni}$ 基超合金が望まれる.

これまで筆者らは熱膨張係数と高温強度におよぼす合 金元素の影響について実験を行い, 蒸気タービン用のボ ルト, ブレード用として $12 \mathrm{Cr}$ フェライト耐熱鋼並に熱 膨張係数が低く，従来の $\mathrm{Ni}$ 基超合金 Refractaloy $26^{\circledR} （ \mathrm{Fe}-$ $38 \mathrm{Ni}-18 \mathrm{Cr}-20 \mathrm{Co}-3.2 \mathrm{Mo}-2.6 \mathrm{Ti}-0.2 \mathrm{Al}$ ) 並に高温強度が高い $\mathrm{Ni}$ 基超合金「LTES700」（Ni-12Cr-18Mo-0.9Al-1.15Ti）を開 発した ${ }^{5)}$.

LTES700 は $\gamma^{\prime}\left[\mathrm{Ni}_{3}(\mathrm{Al}, \mathrm{Ti})\right]$ 相と Laves 相 $\left[\mathrm{Ni}_{2}(\mathrm{Cr}, \mathrm{Mo})\right]$ の 2 種類を複合析出させることにより, $700{ }^{\circ} \mathrm{C}$ までは優 れた特性を有している。しかしながら, LTES700の Laves 相は $750{ }^{\circ} \mathrm{C}$ 付近で消失し, 強化に寄与しなくなることが 確認されている. A-USC プラントで発電効率をさらに向 上させるためには蒸気温度が $750{ }^{\circ} \mathrm{C}$ から $800{ }^{\circ} \mathrm{C}$ に達する

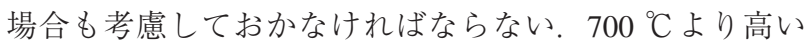
温度域で安定した高温強度を確保するためには，高温ま で安定である $\gamma^{\prime}$ 相のみによる析出強化とした材料が必 要となる。ささらに, タービンローターのような大型部品 を製造するためには，熱間加工性や溶接性などの製造性 がよいことも求められる.

本報では $\gamma^{\prime}$ 相のみによって強化され，既存の $\mathrm{Ni}$ 基超 合金と同等の高温強度を有し, $12 \mathrm{Cr}$ フェライト系耐熱鋼 並に熱膨張係数が低い A-USC 蒸気タービン用 $\mathrm{Ni}$ 基超合 金として開発した「LTES700R」の合金設計の考え方と機 械的性質について報告する.

\section{2. 合金設計}

\section{1 考え方}

Laves 相の析出を抑制し， $\gamma^{\prime}$ 相のみを析出させるため には Laves 相の形成元素であるMo 量を低減する必要が ある。しかしながら, Mo は熱澎張係数（以下 CTE）の 低減に有効であるため, LTES700 と同等の低いCTEを保 つためにはMo 以外の他の元素でMo を置き換える必要 がある、筆者らはこれまでにCTEは式 (1)で予測できる ことを明らかにしており5), Mo と同様に CTE 低減に有 効な元素として W が挙げることができる.
$\mathrm{CTE}=13.87+7.28 \times 10^{-2} \times \mathrm{Cr}+3.75 \times 10^{-2} \times$ $(\mathrm{Ta}+1.95 \mathrm{Nb})+1.98 \times 10^{-2} \times \mathrm{Co}+7.3 \times 10^{-5} \times \mathrm{Co}^{2}-1.84$ $\times 10^{-2} \times \mathrm{Al}-7.95 \times 10^{-2} \times \mathrm{W}-8.24 \times 10^{-2} \times \mathrm{Mo}-$ $1.63 \times 10^{-1} \times \mathrm{Ti}$

一方で $\mathrm{W}$ 量が多過ぎる場合には $\alpha-\mathrm{W}$ 相の生成により, 勒性を損なう可能性がある ${ }^{5)}$. 従って, $\gamma^{\prime}$ 相単独で強 化されるCTEの低い合金を開発するためには，W 量を $a-\mathrm{W}$ 相が生成しない上限までの添加とし， かつ Mo 量 を Laves 相が生成しなくなるまで低減することが必要と なる。

\section{2 タングステン量の検討}

まず W 量の上限を把握するため, $\mathrm{Mo}+1 / 2 \mathrm{~W}$ 質量 $\%$ を 一定に保ったまま $\mathrm{W}$ 量を増加させ， $a-\mathrm{W}$ 相生成の有無 を調査した．Mo量と W 量は質量％での和を一定に保ち， CTEの変化を抑えるために $\mathrm{Mo}+1 / 2 \mathrm{~W}$ 量で整理してい る. Table 1 に供試材 LTW3，6，7，8，およびLTES700 の組成を示し, Fig.1 にそれぞれの Mo 量と W 量の位置 付けを示す. LTW3, 6, 7, 8 の Mo+1/2W 量はCTEを LTES700 と同等とするため 17.7 mass\%とした，加えて，

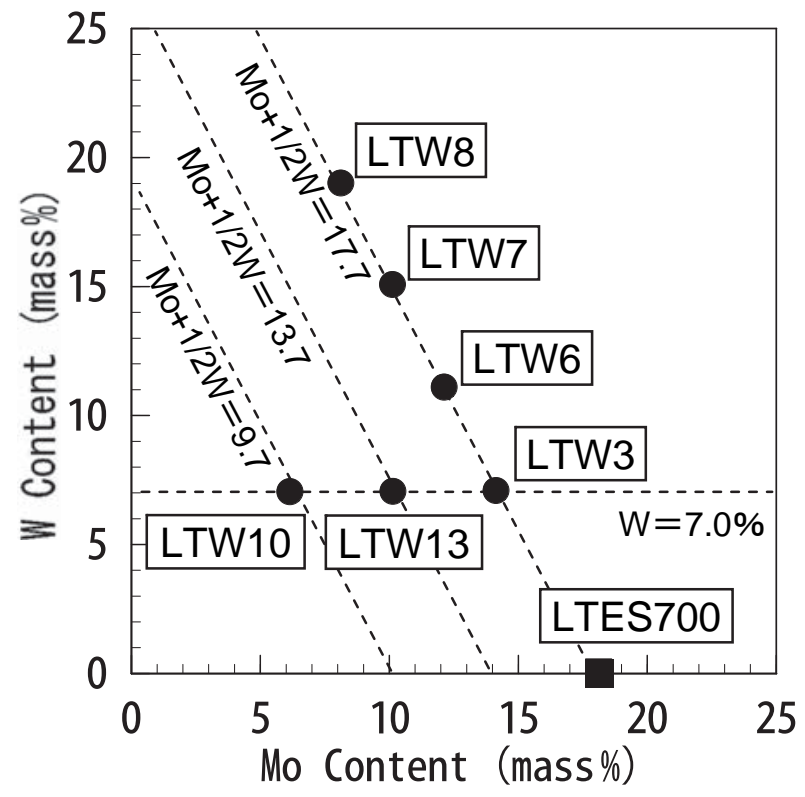

Fig.1. Mo and W contents in the designed alloys and LTES700.

Table 1. Chemical composition of experimental alloys (mass\%).

\begin{tabular}{c|c|c|c|c|c|c|c|c|c|c|c}
\hline Alloy & $\mathrm{C}$ & $\mathrm{Cr}$ & $\mathrm{Mo}$ & $\mathrm{W}$ & $\mathrm{Al}$ & $\mathrm{Ti}$ & $\mathrm{Co}$ & $\mathrm{Fe}$ & $\mathrm{Ni}$ & $\mathrm{Mo}+1 / 2 \mathrm{~W}$ & $\mathrm{Al}+\mathrm{Ti}(\mathrm{at} . \%)$ \\
\hline LTW3 & 0.029 & 12.0 & 14.2 & 7.0 & 1.48 & 0.91 & - & - & bal. & 17.70 & 4.64 \\
\hline LTW6 & 0.032 & 12.0 & 12.2 & 11.0 & 1.54 & 0.91 & - & - & bal. & 17.70 & 4.88 \\
\hline LTW7 & 0.034 & 12.1 & 10.2 & 15.0 & 1.55 & 0.90 & - & - & bal. & 17.70 & 4.99 \\
\hline LTW8 & 0.032 & 12.1 & 8.2 & 19.0 & 1.49 & 0.92 & - & - & bal. & 17.70 & 4.99 \\
\hline LTW10 & 0.031 & 12.0 & 6.2 & 7.0 & 1.50 & 0.90 & - & - & bal. & 9.70 & 4.52 \\
\hline LTW13 & 0.031 & 12.0 & 10.2 & 7.0 & 1.47 & 0.90 & - & - & bal. & 13.70 & 4.57 \\
\hline LTES700 & 0.030 & 12.0 & 18.1 & 0.06 & 0.87 & 1.29 & - & - & bal. & 18.13 & 3.49 \\
\hline Refractaloy26 & 0.03 & 18 & 3.2 & - & 0.2 & 2.6 & 20 & bal. & 38 & 3.2 & 3.53 \\
\hline
\end{tabular}


Laves 相を析出させないことによる強度低下を補うために $\mathrm{Al}+\mathrm{Ti}$ 量を増加した。

Fig.2 に LTW3，6，7，8 の光学顕微鏡写真を示す。相 同定のため，10\%AA 液（10\%アセチルアセトン+ $5 \%$ テトラメチルアンモニウム+メタノール溶液）による 電解抽出を行い, 抽出残渣の X 線回折を行った結果を Fig.3に示す.W 量が 7 mass\% の LTW3 では $\mathrm{M}_{6} \mathrm{C}$ 炭化 物のみが同定されたが，W 量が 11 mass\% 以上の LTW6, LTW7, LTW8 では $\mathrm{M}_{6} \mathrm{C}$ 炭化物に加えて $\alpha-\mathrm{W}$ 相が生成 することが確認された。これにより $\mathrm{W}$ 添加量の上限は 7
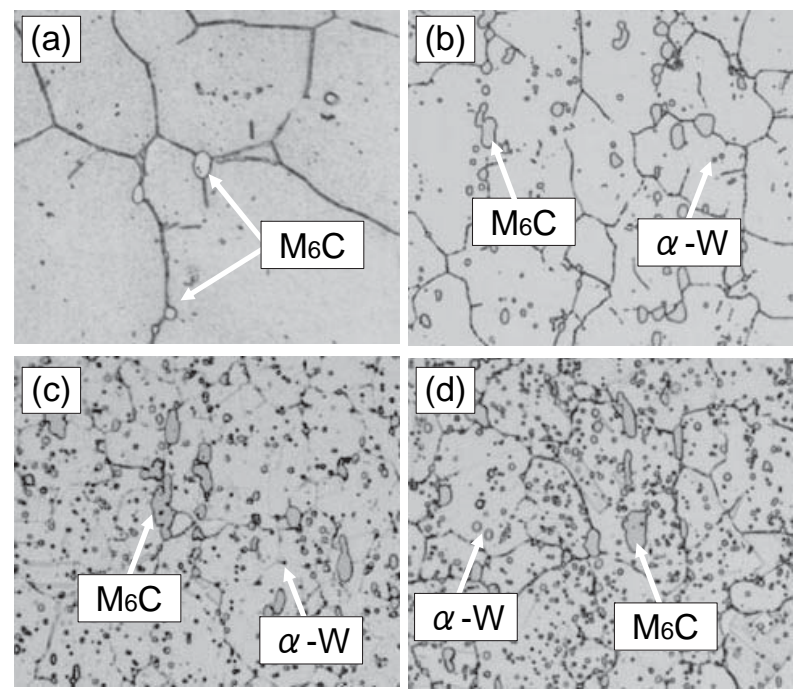

$50 \mu \mathrm{m}$

Fig.2. Microstructure of designed alloys.(a)LTW3,(b)LTW6,(c)LT W7,(d)LTW8.

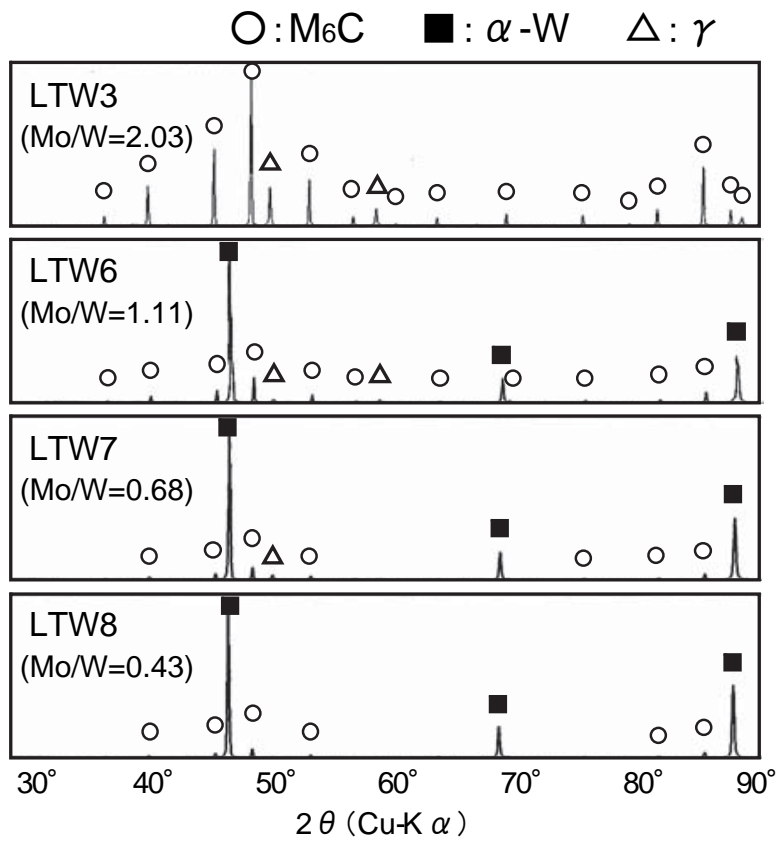

Fig.3. X-ray analysis of LTW3,6,7,8. mass\%であることが明らかとなった

\section{3 モリブデン量の検討}

次に，Laves 相の生成に㧍よぼす Mo 量の影響を調査す るため, Mo 量を 10 mass\% とした LTW13 と 6 mass\% ま で低減したLTW10を設計した。いずれの供試材も $a-\mathrm{W}$ 相が生成しないようにW 量は LTW3 と同等の 7 mass\% と した。 Laves 相の生成有無を確認するために Laves 相の 析出温度である $600{ }^{\circ} \mathrm{C}$ で 1000 時間時効し， LTW3，10, 13 の組織観察を行った. Fig.4に 10 \%AA 溶液でエッチ ングしたSEM 観察組織を示す。Mo 量が 14 mass\%の LTW3 と 10 mass\% の LTW13 では Laves 相が析出するが, Mo 量が 6 mass\% の LTW10 では Laves 相は確認されず, Laves 相の生成を抑制するためにはMo 量を 6 mass\%ま で低減する必要があることが明らかとなった，LTW10 は $600{ }^{\circ} \mathrm{C}, 650{ }^{\circ} \mathrm{C}, 700{ }^{\circ} \mathrm{C}$ のいずれの温度で長時間保持して も Laves 相と $a-\mathrm{W}$ 相のどちらも生成せず，相安定性が高 いことが確認された。 LTW10を開発合金として選定し， 「refined」のRを取って「LTES700R」と命名した.
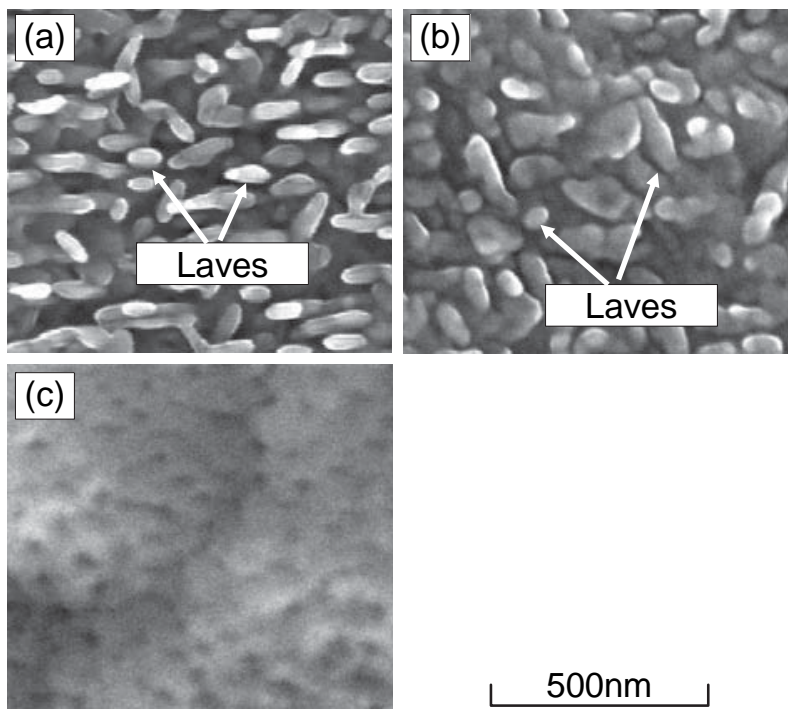

Fig.4. SEM images after $600{ }^{\circ} \mathrm{C}, 1000 \mathrm{hrs}$ aging. (a) LTW3 (14.2 $\%$ Mo), (b) LTW13 (10.2\%Mo), (c) LTW10 (6.2\%Mo).

\section{LTES700R の特性}

\section{1 供試材および実験方法}

Table 2 に特性評価を行ったLTES700Rの組成を示す。 $\mathrm{Al}$ 量と $\mathrm{Ti}$ 量は製造時に変動し易いため, $\mathrm{Ti} / \mathrm{Al}$ 比の影響 についても同時に調査した。供試材を真空誘導炉で溶解 し, 直径 $140 \mathrm{~mm}$, 高さ $380 \mathrm{~mm}$ の $50 \mathrm{~kg}$ インゴットを作 製した。その後，直径 $15 \mathrm{~mm}$ の棒材へ鍛造した。棒材 は $1100{ }^{\circ} \mathrm{C}, 2$ 時間の溶体化処理後水冷され, 種々の条件 で時効処理を行い, 硬さ測定および組織観察を行った。 
Table 2. Chemical composition of LTES700R (mass\%).

\begin{tabular}{c|c|c|c|c|c|c|c|c|c}
\hline Alloy & $\mathrm{C}$ & $\mathrm{Cr}$ & $\mathrm{Mo}$ & $\mathrm{W}$ & $\mathrm{Al}$ & $\mathrm{Ti}$ & $\mathrm{Ni}$ & $\mathrm{Al}+\mathrm{Ti}(\mathrm{at} . \%)$ & $\mathrm{Ti} / \mathrm{Al}$ \\
\hline LTES700R-1 & 0.031 & 12.0 & 6.2 & 7.0 & 1.50 & 0.90 & bal. & 4.52 & 0.60 \\
\hline LTES700R-2 & 0.030 & 12.0 & 6.2 & 7.0 & 1.66 & 0.67 & bal. & 4.58 & 0.40 \\
\hline
\end{tabular}

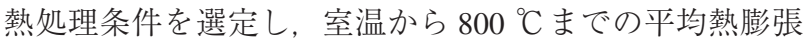
係数の測定と, 室温から $700{ }^{\circ} \mathrm{C}$ までの引張試験，および $600{ }^{\circ} \mathrm{C}$ から $750{ }^{\circ} \mathrm{C}$ までのストレスーラプチャー試験を行っ た。

\section{2 時効硬化特性}

Fig. 5 に $700{ }^{\circ} \mathrm{C}$ から $800{ }^{\circ} \mathrm{C}$ での時効後の硬さを示す. LTES700R は $725{ }^{\circ} \mathrm{C}$ から $775{ }^{\circ} \mathrm{C}$ の一段時効により $30 \mathrm{HRC}$

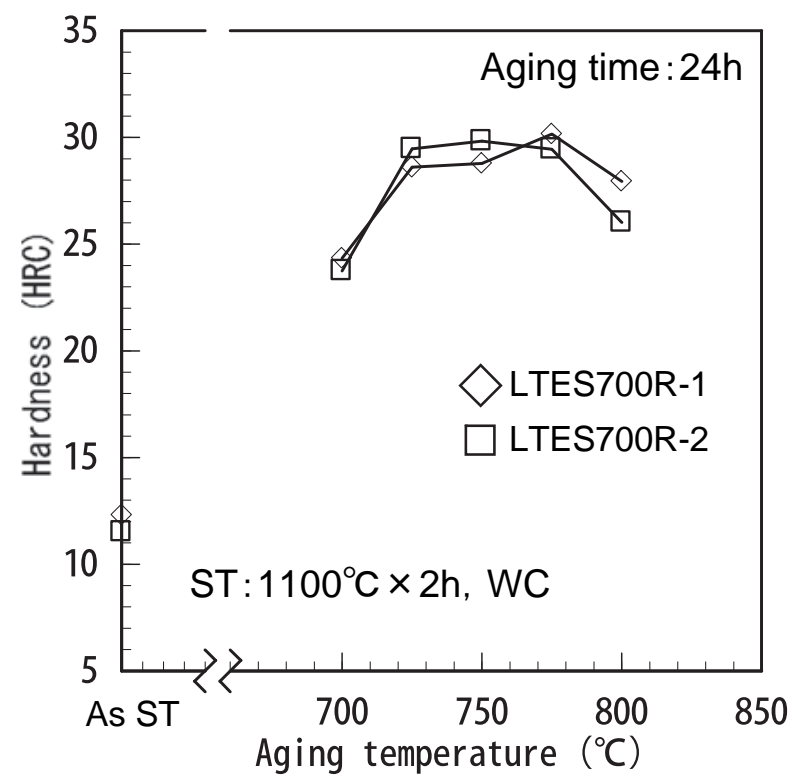

Fig.5. The effect of aging temperature on hardness.

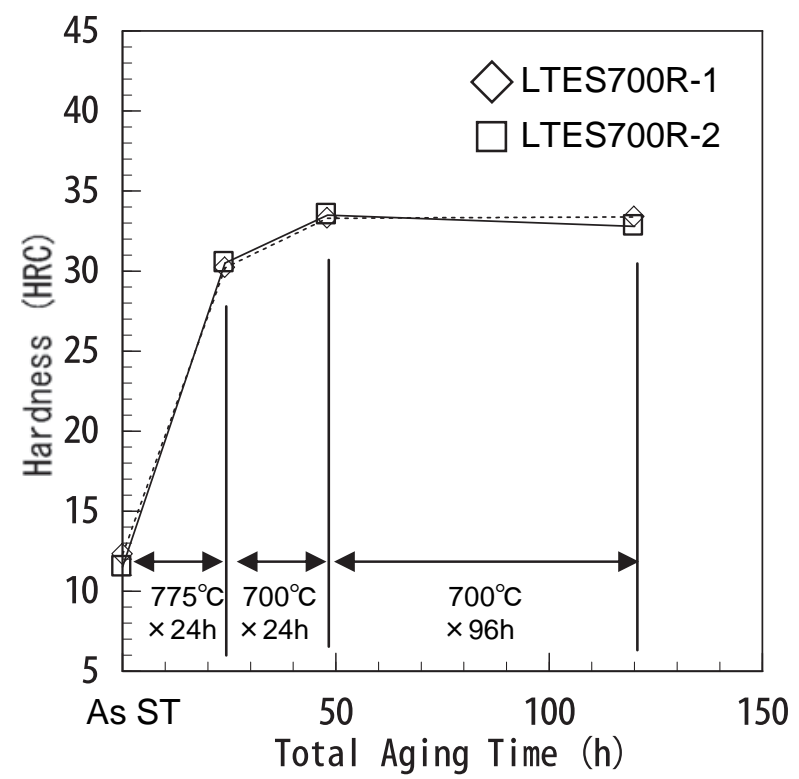

Fig.6. Hardening in the double aging.
以上の硬さが得られる。 LTES700R は $725{ }^{\circ} \mathrm{C}$ から $775{ }^{\circ} \mathrm{C}$ まで一定の硬さであり， $700{ }^{\circ} \mathrm{C}$ 以上でも安定している. Fig.6 は 2 段時効後の硬さを示す。2段時効後には 1 段時 効よりも硬さが $3 \mathrm{HRC}$ 程度上昇した後, 一定の硬さを保つ ている。 Laves 相を使わず $\gamma^{\prime}$ 相のみにより強化されて いるため, LTES700Rの硬さが安定しているものと考え られる。

\section{3 組織}

Fig.7 に 2 段時効後の LTES700R の光学顕微鏡と透過型 電子顕微鏡（TEM）で観察した組織を示す．光学顕微鏡 で観察されるブロック状の析出物は溶体化処理時に未固 溶で残留した $\mathrm{M}_{6} \mathrm{C}$ 炭化物のみであり， $\alpha-\mathrm{W}$ 相は確認さ れない, 一方, TEM 観察では球状に密集して存在する $\gamma$, 相が確認され，LTES700のような Laves 相の生成は確認 されない.

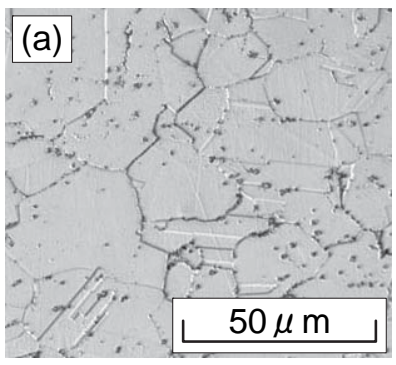

\section{(b)}

Fig.7. Microstructure of LTES700R double-aged. (a)Optical microscope,(b)TEM.

\section{4 熱膨張係数}

室温から $800{ }^{\circ} \mathrm{C}$ までの平均熱膨張係数を, 一般的 な $12 \mathrm{Cr}$ フライト系耐熱鋼と蒸気タービン用合金 Refractaloy26と合わせて Fig.8に示す. LTES700Rは $\mathrm{Mo}+\mathrm{W}$ 量の低減により LTES700よりも高いものの, Refractaloy 26 よりも低く, $12 \mathrm{Cr}$ 鋼に近い熱澎張係数を有 している.

\section{5 機械的性質}

室温と高温での引張強さおよび延性を, LTES700 と 600 ${ }^{\circ} \mathrm{C}$ 級ローター材として使われている新 $12 \mathrm{Cr}$ 鋼 $\left.\mathrm{TMK} 1{ }^{\circledR} 6\right)$ と比較して Fig.9に示す。 LTES700Rの室温での強度は Laves 相を無くしたためLTES700よりも低い一方，700 ${ }^{\circ} \mathrm{C}$ での強度はLTES700 と同等である.TMK1 と比べると, LTES700R は室温で同等の $0.2 \%$ 耐力を有し，高温では高

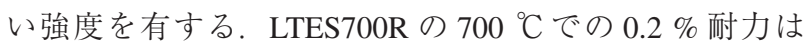




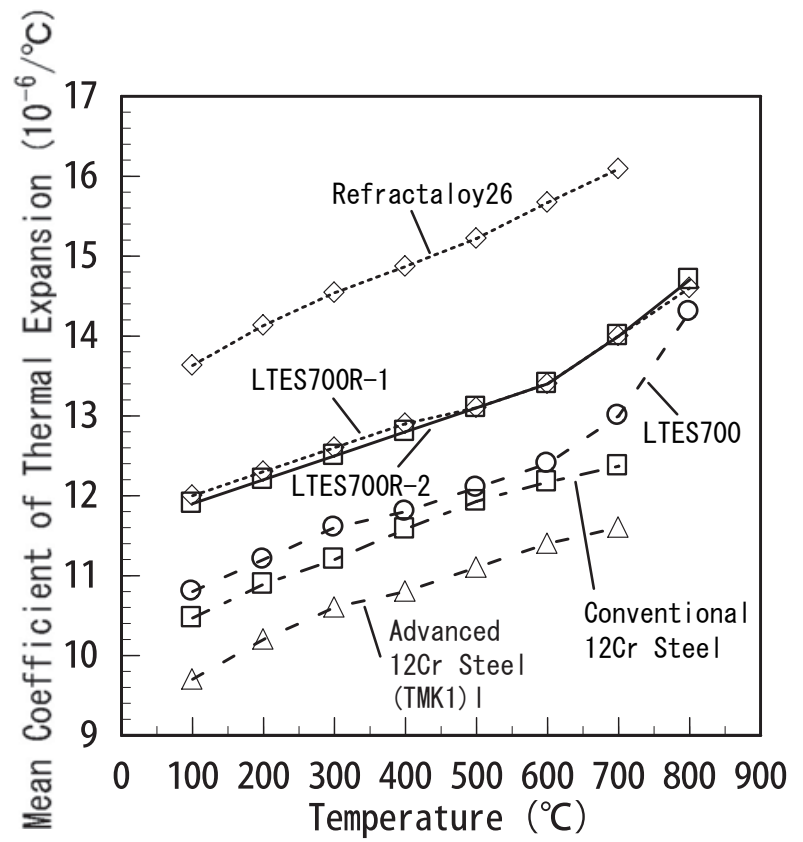

Fig 8. Mean CTE of LTE700R.
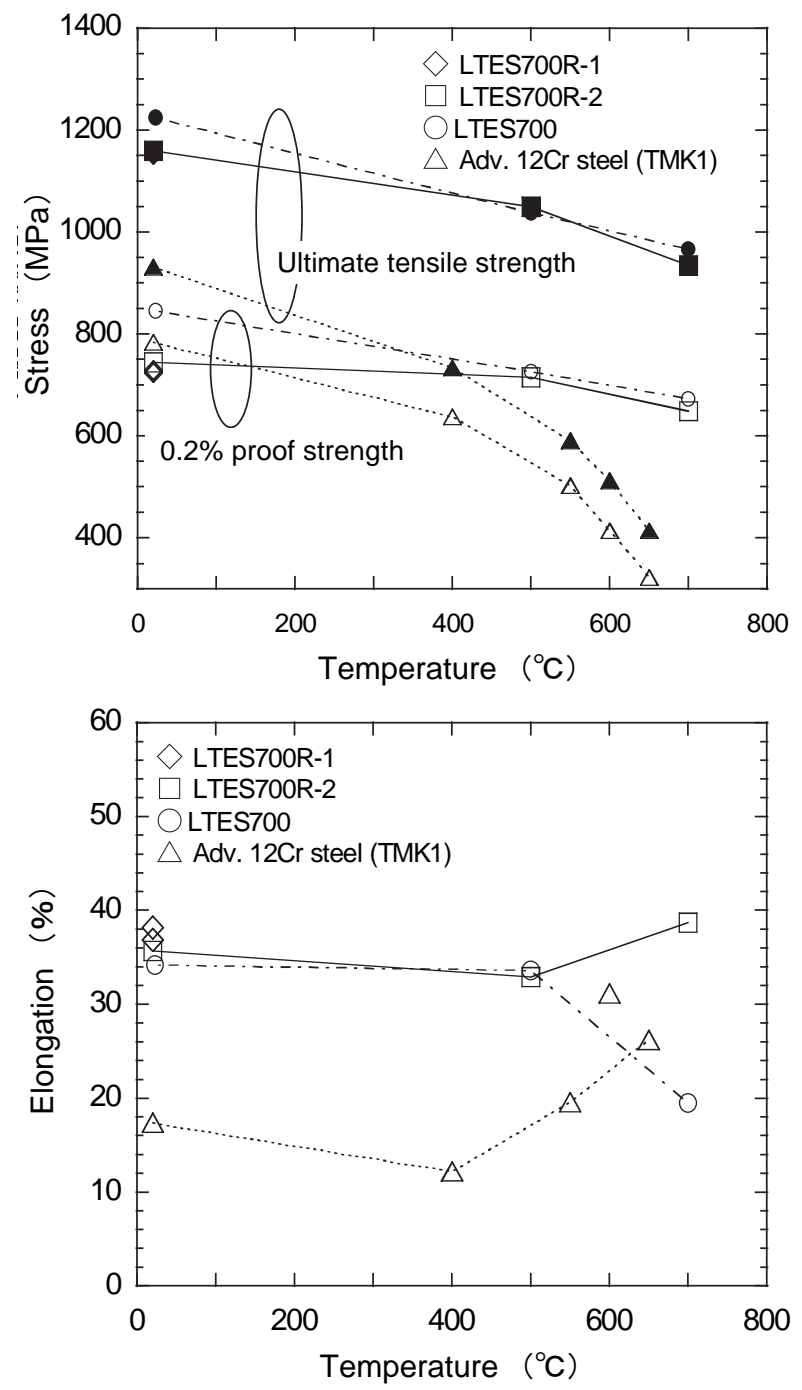

Fig.9. Tensile properties of alloy LTE700R, LTES700 and advanced $12 \mathrm{Cr}$ steel (TMK1).
TMK1 の $600{ }^{\circ} \mathrm{C}$ での $0.2 \%$ 耐力よりも高い.

LTES700R のクリープ破断強度をラーソンミラーパラ メータで整理し, $630{ }^{\circ} \mathrm{C}$ 級タービンのローター材とし て使われている MTR10 ${ }^{\circledR 7)}$ と比較して Fig.10に示す. LTES700R の $700{ }^{\circ} \mathrm{C}, 1000 \mathrm{~h}$ クリープ破断強度は MTR10 よりも $300 \mathrm{MPa}$ 以上高い.

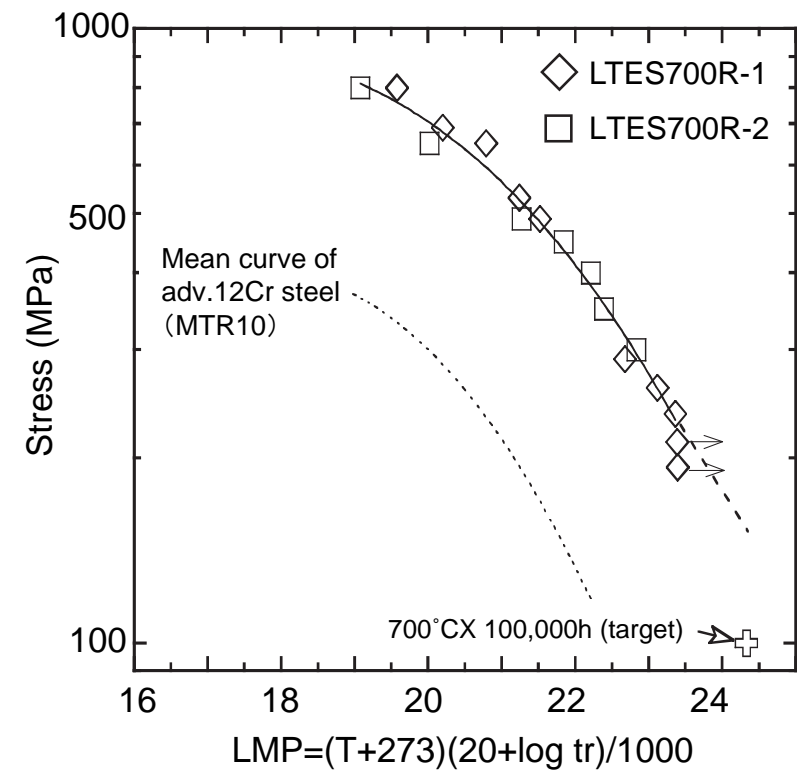

Fig.10. Creep rupture strength of alloy LTES700R and advanced $12 \mathrm{Cr}$ steel.

\section{6 相安定性}

$450{ }^{\circ} \mathrm{C}$ から $700{ }^{\circ} \mathrm{C}$ で長時間加熱後のビッカース硬さを Fig.11に示す。 $30 \mathrm{HV}$ 程度の小さな硬さの変化しかなく, 硬さは安定している. Fig. 12 に $650{ }^{\circ} \mathrm{C} て ゙ 1000$ 時間加熱後 の TEM 観察組織を示す. Fig.6の 2 段時効後の組織と同

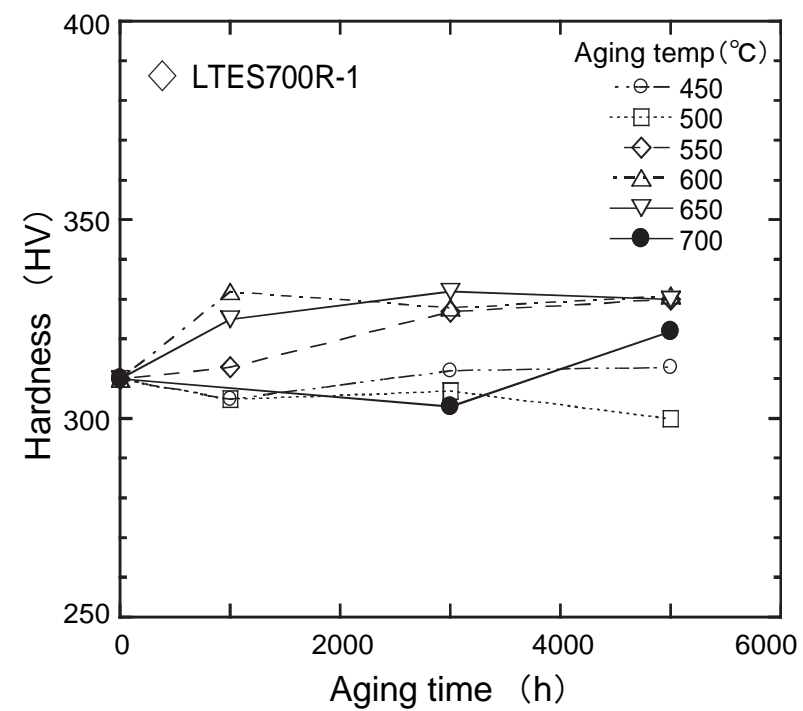

Fig.11. Relationship between Vickers hardness and aging time from $450{ }^{\circ} \mathrm{C}$ to $700{ }^{\circ} \mathrm{C}$. 
様に $\gamma^{\prime}$ 相のみが観察され， LTES700R の相が安定してい ることを示している.

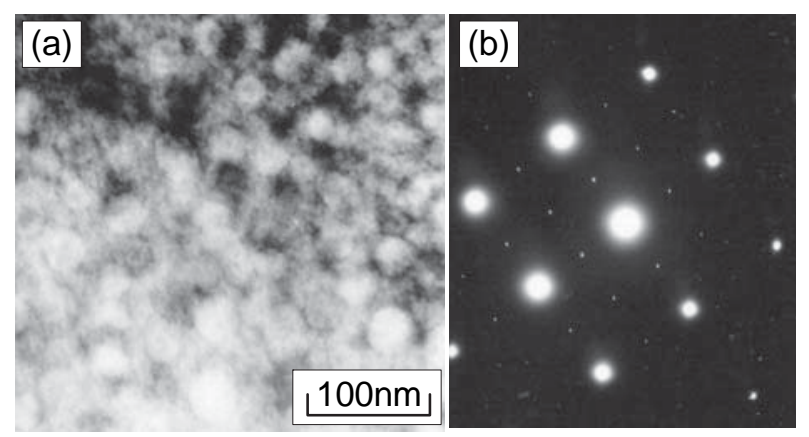

Fig.12. TEM microstructures of alloy LTES700R after $1000 \mathrm{hrs}$ of heating at $650{ }^{\circ} \mathrm{C}$.(a) Bright field image, (b) Electron diffraction pattern $(B=001)$.

\section{4. まとめ}

(1) LTES700R は Laves 相と $\alpha-\mathrm{W}$ 相の生成を抑制して $\gamma^{\text {’ }}$ 相単独での強化とし， かつ熱膨張係数を低くするために LTES700 から Mo 量と W 量を適正化した.

(2)LTES700R の平均熱澎張係数は一般的な超合金 Refractaloy26よりも低く, $12 \mathrm{Cr}$ フェライト系耐熱鋼に近 いレベルである.

(3)LTES700R は室温で新 $12 \mathrm{Cr}$ 鋼 (TMK1) に近い $0.2 \%$ 耐 力を有し, 高温での強度, 特に引張強さと伸びに優れて いる.

(4)LTES700R の $700{ }^{\circ} \mathrm{C}, 1000 \mathrm{~h}$ クリープ破断強度は $630{ }^{\circ} \mathrm{C}$ 級タービンロータ材 (MTR10) よりも $300 \mathrm{MPa}$ 以上高い.

(5)LTES700R は $450{ }^{\circ} \mathrm{C}$ か $700{ }^{\circ} \mathrm{C}$ までの温度で相安定性 に優れている.

(6)LTES700R は A-USC 蒸気タービン用材料として有望な 材料であり，今後量産規模での大型品の製造性を確立し， 実機への適用検討を進めていく予定である.

\section{(文 献)}

1) R. Blum and R. W. Vanstone: Proceedings of the $8^{\text {th }}$ Liege conference, Liege, (2006), 41.

2) R. Viswanathan, J. F. Henry, J. Tanzosh, G. Stanko, J. Shingledecker and B. Vitalis: Proceeding from the Fourth International Conference on Advanced in Materials Technology for Fossil Power Plants, (2005), 3.

3) M. Sato, M. Yaguchi, Y. Tanaka, J. Iwasaki, M. Fukuda, E. Saito, H. Nakagawa, A. Shiibashi and S. Izumi: The THERMAL AND NUCLEAR POWER, 57 (2006), 89.

4) R. Yamamoto, Y. Kadoya, S. Ueta, T. Noda, R. Magoshi, S. Nishimoto and T. Nakano: ibid 2., 623.
5）山本隆一, 角屋好邦, 河合久孝, 馬越龍太郎, 植田茂紀, 野田俊治，磯部晋：鉄と鋼，90 (2004), 37.

6) Y. Nakabayashi, A. Hizume, Y. Takeda, Y. Takano, T. Fujikawa, H. Yokota, A. Suzuki, S. Kinoshita, M. Koono and T. Tsuchiyama: The First International Conference on IMPROVED COAL-FIRED POWER PLANTS, (1986), 8.

7) Y. Kagawa, F. Tamura, O. Ishiyama, O. Matsumoto, T. Honjo, T. Tsuchiyama, Y. Manabe, Y. Kadoya, R. Magoshi and H. Kawai: Proceedings of the $14^{\text {th }}$ International Forgemasters Meeting 2000 (2000), 301. 